УДК 94(571.150)

DOI 10.37386/2687-0592-2020-10-258-2611

\title{
А. А. Гоппе, И. А. Панченко
}

\section{Создание научного бренда как эффективный способ продвижения результатов исследовательской деятельности на примере проекта «Устная история и этнография в полевых исследованиях второй половины XX - начала XXI в. как источник и метод изучения и сохранения историко-культурного наследия сельских территорий Алтайского края ${ }^{1}$}

Аннотация. В статье на примере реализации первого года проекта РФФИ «Устная история и этнография в полевых исследованиях второй половины XX - начала XXI в. как источник и метод изучения и сохранения историко-культурного наследия сельских территорий Алтайского края» демонстрируется построение научного бренда. На основе ряда фактов доказывается эффективность продвижения результатов исследования с помощью созданного сайта. Показана структура информационного ресурса, приведен пример статистики охвата публики, а также намечена дальнейшая перспектива ресурса. Показана структура информационного ресурса, рассмотрен изданный библиографический указатель, дается их оценка с точки зрения востребованности как научным сообществом, так и региональной общественностью в целом. Намечена дальнейшая перспектива развития проекта. Ключевые слова: полевые исследования, этнография, устная история, культурная антропология, историко-культурное наследие, Алтайский край, научный бренд.

В результате исторических процессов, связанных с рядом переселений и миграций, которые проходили в контексте государственной политики на протяжении XVIII-XX вв., население Алтайского края имеет пестрый историко-культурный состав. Кроме этого, крестьянское население долгое время являлось хранителем этнических традиций, а аграрный характер Алтайского края на протяжении длительного периода способствовал консервации этих традиций, благодаря чему население Алтайского края является привлекательным объектом для этнографических исследований [1, с. 124].

Изучение этнокультурного наследия сельских территорий Алтайского края берет начало еще в XIX в., однако наиболее планомерные исследования начались во второй половине XX в. экспедициями ведущих научных центров Москвы и Санкт-Петербурга, но массовый характер оно приобрело в 19802010-е гг., когда сформировались региональные научные центры и научные школы (Новосибирск, Омск, Томск, Бийск, Барнаул). На протяжении этого времени был накоплен значительный источниковый материал, созданы коллекции материального и устного наследия. Поэтому, с одной стороны, возникает необходимость обобщить и систематизировать накопленные полевые материалы, с другой стороны их анализ позволит выйти на новый уровень монографического обобщения истории изучения историко-культурного наследия сельских территорий $[2,3]$.

1 Исследование выполнено при финансовой поддержке РФФИ и Министерства образования и науки Алтайского края в рамках научного проекта № 19-49-220009 «Устная история и этнография в полевых исследованиях второй половины XX - начала XXI века как источник и метод изучения и сохранения историко-культурного наследия сельских территорий Алтайского края».
Благодаря финансовой поддержке РФФИ с 2019 г. научным коллективом Центра устной истории и этнографии Алтайского государственного педагогического университета в составе канд. ист. наук, зав. историко-краеведческим музеем АлтГПУ Н. С. Грибановой, аспирантов кафедры отечественной истории А. В. Рыкова, Н. В. Люля, А. А. Гоппе под руководством д-ра ист. наук, проф. Т. К. Щегловой реализуется научно-исследовательский проект «Устная история и этнография в полевых исследованиях второй половины XX - начала XXI в. как источник и метод изучения и сохранения историко-культурного наследия сельских территорий Алтайского края». Новационность проекта заключается в рассмотрении не только культурного ландшафта сельского поселения, но и исторической памяти его населения, что позволяет проследить процесс развития народов и их культур в контексте исторических событий XX в. с учетом особенностей региональной истории.

В рамках проекта реализуется синергия технологий и методик устной истории, этнографии, культурной и социальной антропологии, благодаря чему изучение сельских территорий Алтайского края выходит на новый уровень. Отличительной чертой проекта является использование IT-технологий, возрастающая роль которых неоспорима: современные исследования все больше переходят в цифровую плоскость. Поэтому на примере проекта «Устная история и этнография в полевых исследованиях второй половины XX - начала XXI в. как источник и метод изучения и сохранения историко-культурного наследия сельских территорий Алтайского края» авторы предпринимают попытку охарактеризовать возможности создания научного бренда как эффективного способа продвижения результатов исследо- 
вательской деятельности с использованием информационно-коммуникационных технологий.

Для историков мобилизация новых технологий на основе междисциплинарного подхода открывает широкий спектр возможностей, в том числе в изучении региональных особенностей истории и культуры населения и введения в научные тексты результатов полевых исследований отечественных научных центров и школ второй половины XX - начала XXI в. В этой связи удобное всестороннее взаимодействие с потребителем информации в поле быстро развивающихся медиа-каналов становится одной из важнейших задач не только для коммерческого сектора экономики, но и для научной среды. Любая научная организация или учебное заведение сегодня существует в определенных конкурентных рамках, при этом в одних сферах деятельности они могут быть жестче, в других - мягче. Ежегодно публикуется большое количество научных трудов, монографий, научных исследований, при этом чаще всего они носят локальный характер, а иногда бывают недоступны потребителям информации.

Современные научные исследования призваны привносить в исследовательское поле актуальную повестку, должны быть востребованы в информационной среде и отвечать критериям массовой доступности. Научное исследование сегодня может рассматриваться как высокоинтеллектуальный продукт, который имеет достаточный потенциал для продвижения, при этом реализация этого потенциала лежит в плоскости создания эффективной бренд-коммуникации [6]. Потребитель информации на этапе выбора обращается не только к ее определенным потребительским свойствам, но и к эмоциональным впечатлениям, которые сформировались в процессе восприятия. По мнению М. О. Макашева, при отсутствии явных предпочтений потребитель опирается на: прошлый опыт пользования услугами; рекомендации друзей, коллег, знакомых; ассоциативные впечатления; информационное обеспечение и поддержку во время акта потребления [6].

Следуя плану первого года работы, коллектив авторов проекта создал специализированный информационный ресурс (веб-сайт) «Устная история и этнография в полевых исследованиях второй половины XX - начала XXI века как источник и метод изучения и сохранения историко-культурного наследия сельских территорий Алтайского края» (URL: http://etnografy.altspu.ru/). Сегодня на сайте опубликовано более 50 биографий исследователей. Кроме биографий, на их персональных страницах представлены тематические фотографии, которые иллюстрируют научно-исследовательскую работу каждого ученого, видеоматериалы, а также PDF-варианты их статей. В последующие годы планируется заполнить интернет-ресурс картографическими материалами, архивными собраниями, сведениями о научных, музейных и культурно-просветительских центрах по изучению этнографии и устной истории Алтайского края, результатов работы по проекту (ста- тей, изданий) и др. с целью обеспечения открытого доступа к ним для научного сообщества и широкой общественности. Созданный в ходе реализации проекта интернет-ресурс учитывает как ассоциативные эффекты, так и удобство для пользователя. Анализ обобщенных цветовых характеристик более $70 \%$ интернет-сайтов, связанных с тематикой этнографии и устной истории, показывает, что они используют в своем цветовом ядре оттенки красного, серого и черного цветов. В результате анализа контрольной выборки из 10 интернет-ресурсов был выбран комплементарный подход к использованию этой цветовой гаммы.

Следует отметить, что понятие бренда - достаточно емкое и относится к сфере прикладной маркетинговой деятельности и теоретических аспектов экономической теории. При этом, хотя построение бренда в научной сфере имеет особенности, наиболее верным представляется подход к его определению с точки зрения потребительского восприятия [7]. В этой связи можно выделить определения, предложенные Жан-Ноэль Капферером и Эл Райс. По мнению этих исследователей, «бренд - уникальная идея или концепция, которую вложили в голову потребителя» [8]. В своей работе «22 закона создания бренда» Э. Райс обращает внимание на то, что процесс взаимодействия бренда и потребителя это последовательность психологических и когнитивных процессов; эффективность психологического воздействия автор определяет как «силу бренда». Вице-президент IABC/Russia по инновациям, преподаватель Национального исследовательского университета «Высшая школа экономики» И. А. Балахнин в своих работах указывает, что управлять нужно одновременно и продуктом, и брендом, при этом дает следующее определение: «Бренд - это продукт или услуга, относительно которой потребитель может утвердительно ответить для себя на два вопроса: похож ли этот товар, услуга на меня? Поднимает ли факт использования этого товара, услуги, мой социальный статус в глазах окружающих, значимых для меня людей»? [9]. Научный бренд, в свою очередь, отличается рядом дополнительных черт: более персонифицированными запросами к содержанию, особенностями научной сферы и вида научной деятельности, необходимостью создания высокого уровня доверия к информации, транслируемой брендом.

Таким образом, современному бренду присущи следующие характеристики: индивидуальность как визуальное, так и вербальное выражение (в рамках группы товаров бренд идентифицирует продукт таким образом, что его уникальное торговое предложение является наиболее релевантным для потребителя); бренд-позиционирование - нахождение в определенном сегменте рынка дает возможность работать с тем или иным сегментом целевой аудитории, занимать определенное «уникальное» место на рынке и в потребительском сознании; актуальность - наращивание потребительской лояльности за счет процессов ценностной синхронизации с по- 
требителем; имиджевая аутентичность - связанность всех элементов, внутренней и внешней среды организации; идентичность - основа позиционирования, представление о том, что заключает в себе бренд, его планируемый образ; ценности бренда - черты, которые мотивируют желание потребителя ассоциировать себя с ним. Бренд существует не только в сознании потребителя, но и в этосе, психографических и ассоциативных особенностях, которых бренд стремится достичь.

Накопление необходимого объема исследовательской информации, проведение качественных и количественных исследований - неотъемлемая часть построения бренда, точно нацеленного на взаимодействие с отобранными группами целевой аудитории. В построении научного бренда наиболее эффективной предполагается реструктуризация предложенных исследователем этапов по группам: «до-брендинг», производство продукта, тестирование, ребрендинг - старт конечного потребительского продукта. В группу «до-брендинга» включены: определение потребности в бренде, генерация идеи, постановка задач, нейминг, выбор канала коммуникации, при этом этап анализа и тестирования широких групп целевой аудитории предполагается проводить на готовом материале, собранном на основе анализа предпочтений экспертной группы.

Проект «Полевые исследования по этнографии и устной истории на территории Алтайского края во второй половине XX в.» является примером построения научного бренда, нацеленного на продвижение результатов научных исследований в интернете и входит в группу общего бренда «Центр устной истории и этнографии Алтайского государственного педагогического университета», который представляет собой «зонтичный бренд-конструктор», собираемый из группы научных проектов. А. Уиллер определяет возведение архитектуры бренда в формировании «взаимоотношений материнской информационной среды, дочерних проектов, продуктов и услуг» $[7,10]$.

Для наиболее быстрого охвата целевой аудитории основным каналом продвижения был выбран интернет. Создание места во всемирной паутине и занятие информационной ниши исходило из выбора конкурентного доменного имени и определения технических требований к интернет-ресурсу. Проведение анализа поисковых запросов в сервисе «Yandex. wordstat» показало, что основные поисковые запросы, интересующие исследователей в области этнографии и истории, включают теги: этнография, устная история, исследователи, музей этнографии, фольклор. Немаловажным было указание и территориальной принадлежности. На основе этих результатов было сформировано соответствующее семантическое ядро сайта, на базе которого были заполнены все страницы для увеличения их поискового потенциала. Формат интернет-ресурса был определен как база исследователей с возможностью размещения полной информации о персоналиях, а также со- здания репозиториев научно-исследовательских публикаций. На текущем этапе разработки интернетресурса сформирована цветовая композиция, активно коррелирующая с цветами ведущего бренда, а интернет-ресурс с конкурентным доменным именем etnografy.altspu.ru за четыре месяца работы вышел на посещаемость в 150 человек в день. Поисковыми сервисами проиндексированы более 500 страниц сайта и выведены в поиск более 200 публикаций из репозиториев исследователей. Основной задачей сегодня является адаптация интернет-ресурса под мобильные устройства и вовлечение исследователей в активную двустороннюю работу через создание форм взаимодействия с потребителем, когда каждый автор сможет предложить свои научные работы, которые будут опубликованы и проиндексированы поисковыми системами. Активное использование визуальных якорей, таких как фотогалереислайдеры, позволяет представителям целевой аудитории задержаться на сайте. Так называемая «посадочная страница» для интернет-ресурса чаще всего является и стартовой. Посетители сайта, уделяют просмотру старых фотоматериалов до 2 минут. Таким образом увеличивается показатель вовлеченности. Приследуется цель вызвать интерес у посетителя сайта и создать ситуацию “исторической синхронизации" благодаря использованию обширной базы фотоматериалов. Подобный подход повышает интерес как к самому интернет-ресурсу, так и к личностям отдельных исследователей.

Создание научного бренда на данный момент находится на этапе анализа, что предполагает получение основных качественных и количественных сведений по вопросам удобства, основных потребностей гостей интернет-ресурса и постоянной оценки влияния цвета и символов в графическом оформлении. После сбора более полной статистической информации предполагается проведение дополнительного исследования методами фокус-групп и панельной дискуссии, а также переход к этапу корректировки бренда.

Подводя итог, следует отметить, что построение научного бренда представляет собой трудоемкую задачу, в основе которой лежит объединение информационных потребностей представителей научного сообщества и создание доступной информационной базы с высоким уровнем доверия. Проведена активная и всесторонняя работа на этапе «до-брендинга» и вывод проекта на этап анализа, сбора качественной и количественной информации. В свою очередь, успешно завершен первый год работы над проектом, заложен фундамент для дальнейшей его реализации и выхода на качественно новый уровень. Особое внимание следует уделить также тому, что работа коллектива исследователей Центра устной истории и этнографии АлтГПУ положит начало комплексному изучению истории этнографических и устноисторических исследований наследия сельских территорий Алтайского края, а полученные данные будут способствовать расширению и углублению методологиче- 
ской базы полевых исследований, в том числе в цифровой сфере.

\section{A. A. Goppe, I. A. Panchenko}

Create a scientific brand as an effective way to promote the results of research activities on the example of the project "Oral history and ethnography in field research in the second half of the XX - early XXI century as a source and method of studying and preserving the historical and cultural heritage of rural areas of the Altai Territory

Annotation. The article demonstrates the construction of a scientific brand using the example of the implementation of the first year of the RFBR project "Oral history and ethnography in field research in the second half of the 20th - early 21st centuries as a source and method of studying and preserving

\section{Источники и литература}

1. Щеглова Т. К. Многоликий мир алтайских деревень // Алтайский благодатный край. Москва, 2007. C. $124-129$.

2. Полевые исследования по этнографии и устной истории Алтайского края в 1950-2010-е гг:: библиогр. темат. науч.-вспомогат. указатель / науч. ред. Т. К. Щеглова; сост. Т. К. Щеглова, А. В. Рыков, А. А. Гоппе, Н. С. Грибанова, Н. В. Люля. Барнаул: АлтГПУ, 2020. 336 с.

3. Батьянова Е. П. Род и община у телеутов в XIX начале XXI века: [монография] / Е. П. Батьянова ; Рос. акад. наук, Ин-т этнологии и антропологии им. Н. Н. Миклухо-Маклая. Москва: Наука, 2007. 394 с.

4. Щеглова Т. К. Этнографические исследования в Алтайском крае: история и современность // Полевые исследования в Верхнем Приобье и на Алтае, 2007 г.: археология, этнография, устная история: материалы 4-й регион. науч.-практ. конф., 6-8 дек. the historical and cultural heritage of the Altai Territory". On the basis of a number of facts, the effectiveness of promoting research results with the help of the created site is proved. On the basis of a number of facts, the effectiveness of promoting research results with the help of the created site is proved. The structure of the information resource is shown, an example of statistics of public coverage is given, and the further perspective of the resource is outlined. The structure of the information resource is shown, and the published bibliographic index is also considered, and their assessment is given from the point of view of the demand both by the scientific community and the regional community as a whole. The further perspective of the project development is also outlined. Keywords: field research, ethnography, oral history, cultural anthropology, historical and cultural heritage, Altai Territory, scientific brand.
2007 г. / Алт. гос. пед. акад., лаб. ист. краеведения; редкол.: М. А. Демин, Т. К. Щеглова, А. Н. Телегин. Барнаул: АлтГПА, 2009. Вып. 4. С. 171-186.

5. Макашева 3. М. Макашев М. О. Брендинг: учеб. пособие. Санкт-Петербург: Питер, 2011. 288 с

6. Траут Д. Дифференцируйся или умирай! [Текст]: выживание в эпоху убийственной конкуренции / Д. Траут, С. Ривкин ; [пер. с англ. Е. Колотвина]. 2-е изд., обновл. и доп. Санкт-Петербург: Питер, 2012. $302 \mathrm{c}$.

7. Перция В. Н., Панин А. К. Анатомия бренда 2: Диалектика. Москва: ОМЕГА-Л, 2011. 240 с.

8. Балахнин И. Горизонтальный мир: Экономика, инновации, новые медиа. Москва: Балахнин Илья Александрович, 2012. 694 с.

9. Уиллер А. Индивидуальность бренда. Руководство по созданию, продвижению и поддержке сильных брендов. Москва: Альпина Бизнес Букс, 2004. 235 с.

УДК 39(092)+94(571.150)

DOI 10.37386/2687-0592-2020-10-261-263

\section{B. Г. Дацышен}

Сибирский федеральный университет, Красноярский государственный педагогический университет, г. Красноярск, Российская Федерация

\section{Алтайский эпизод службы этнографа К. М. Рычкова ${ }^{1}$}

Аннотация. В работе показана малоизвестная страница биографии известного этнографа К. М. Рычкова. В сентябре 1920 г. он составе советской делегации ездил на переговоры с властями Алтайского округа Китайской Республики. К. М. Рычков обратил внимание на национальный вопрос в этом китайском регионе. Ключевые слова: К. М. Рычков-Ракай, Алтай, Монгольский вопрос, советско-китайские переговоры.

В истории российской этнографии оставил заметный след Константин Михайлович Рычков (псевдоним - Ракай, 1882-1923). Он родился и значительную часть своей жизни проживал в Усть-Каменогорске, известность в науке получил благодаря своим исследованиям в Туруханском крае. В его биогра-

\footnotetext{
${ }^{1}$ Исследование осуществляется при финансовой поддержке гранта РФФИ. Проект «Влияние неравномерного развития регионов России и Китая на межрегиональное двустороннее сотрудничество: сравнительно-историческое исследование» №20-014-00010
}

фии был интересный эпизод поездки на китайский Алтай. В его некрологе указывалось: «В 1920 г. он окончательно подрывает здоровье, пробираясь через горные хребты в Монголию для определения военной границы с Китаем...» [1, с. 249]. Речь шла о поездке в составе советской делегации на переговоры с властями Алтайского округа Китайской Республики в сентябре 1920 г.

Уроженец Усть-Каменогорска К. М. Рычков в молодые годы за революционную деятельность был сослан в Туруханский край, где впервые занялся эт- 